\title{
Teaching of Religious Moderation in the Tarekat For Millennials
}

\author{
Elma Haryani ${ }^{1}$, Lufaefi $^{2}$ \\ \{elmaharyani28@gmail.com ${ }^{1}$, eepivanosky@gmail.com²\} \\ Badan Litbang Kemenag RI ${ }^{1}$, PTIQ Jakarta ${ }^{2}$
}

\begin{abstract}
This paper portrays the teaching of religious moderation in the Mahasiswa (Students) Ahlith Thoriqoh Al-Mu'tabarah An Nahdliyyah (MATAN) organization, Bandung, West Java. This begins with data from several studies which state that some of the middle, upper and higher level students in Bandung are listed as young people who have the potential to have intolerant ideals due to the high level of exclusive Islamic teaching. By using the micro-mobilization mechanism theory, MATAN Bandung teaches religious moderation in the form of tolerance with other groups, commitment to the concept of the Indonesian state, avoiding violence, and accommodating culture. MATAN Bandung's teaching of moderation has an impact on the awareness of ISIS and HTI sympathizers, internal and external conflict zones, and the emergence of sympathizers from outside MATAN. MATAN's moderation teaching harmonizes the intellectual and spiritual elements.
\end{abstract}

Keywords: MATAN, Religious Moderation, Tarekat, Spiritual.

\section{Background}

Research results from the Center for Islamic and Community Studies (PPIM) UIN Jakarta reveal that Islamic Religious Education (PAI) teachers at the primary and secondary education levels tend to be intolerant towards groups of different ideologies, whether Muslim or non-Muslim. The research released in December 2019 revealed the fact that the majority of PAI teachers who have the right to teach Islamic religion to school students reject non-Muslim leadership (PPIM, 2019). In fact, education is a step to empower the younger generation (students) to become intelligent individuals, both spiritually and intellectually, in order to uphold religious values, norms, nationalism, ethics, and science (Faiza, 2018; 116).

There are two reasons why the understanding and rejection of non-Muslim leaders by the younger generation tends to give rise to understanding and actions that are exclusive and intolerant. First, disagreements based on religious reasons will have a major impact on the bad future of the life of the nation and state in this Republic, especially if it is accompanied by acts of violence. Second, expressions of religious supremacy carried out in schools / public spaces have the potential to pose a danger to survival in the context of diversity. Especially considering the teaching responsibility of PAI teachers who teach Islamic religious education to the younger generation of around 34 million Muslim students throughout Indonesia (Tempo, 2019). The author concludes, if you look at the results of the PPIM research above, it can be understood that the future of Islamic teaching and education in Indonesia for the nation's young generation is quite worrying as it continues to lead to the formation of an intolerant and exclusive young generation. 
The above reality needs to be of concern to the Indonesian people, especially the government as policy makers, considering that education is one thing that needs to be prioritized for attention in order to progress a nation. The progress of the nation depends on the progress of education carried out through the younger generation (Veithzal, 2014; 181). If the education and teaching of Islam for young people in Indonesia is still dominated by radical, exclusive and intolerant attitudes and actions, it is not impossible if the education and religious teaching of young people in Indonesia will become a growing field for radicalism, even terrorism.

Education is also a medium that determines a social condition of society either in the present or in the future which is transmitted through the younger generation. Setara Institut stated that every structural opportunity and enabling environment for radicalism and terrorism, which are strategic targets for the spread of radical narratives, and one of them is Higher Education, must get special attention in handling intolerance and radicalism. and the resistance movement to Pancasila (Setara, 2019). It is not something that is ridiculous if education in higher education has become a field for the spread of the intolerant movement among young people. There are some revealing studies. Alvara Institut (2017) released several indicators of intolerance among students, namely the presentation of students who do not support nonMuslim leaders by $29.5 \%$, agreeing with the Islamic state by $23.5 \%$ and agreeing with the caliphate of $23.5 \%$.

Efforts to prevent and minimize the entry of extreme ideologies were also carried out by student organizations under the name Ahlith Thariqoh Al Mu'tabarah An Nahdliyyah (MATAN) Student, which focuses on the spiritual and intellectual teaching of its members, and continues to strengthen the vision of loving the Unitary Republic of Indonesia (NKRI). As stated in the vision of MATAN, that the purpose of forming the student organization is to seek the birth of the next generation and future nation leaders who have intellectual acuity and wisdom and spiritual depth as the basis for building and upholding the glory of the Unitary State of the Republic of Indonesia (NKRI) (Matan DIY, 2014) .

The main focus of this research is to reveal how the teaching of religious moderation is formed in the body of the MATAN branch of Bandung, West Java and is transmitted therein. Seeing the focal point of the activities carried out by the organization on increasing spiritual values that are harmonized with intellectual values, it makes the teaching of religious moderation among millennials interesting to be explored more deeply. The integration of the two is important to become one of the models of religious moderation teaching for young people to give birth to a moderate generation.

\section{Literature Review}

Research around religious moderation from a spiritual perspective is not new. There have been previous studies that also discuss this. To test the novelty of this study with previous studies, it is necessary to mention these previous studies:

First, Manaqib; Moderasi Islam di Tengah Masyarakat Multikultural, written by Muhammad 'Ainul Yaqin (2018). This research proves that tasawuf and dzikir manaqib can enhance the spiritual side, so that humans will arrive at self-happiness and peace in the environment. Thus, someone will behave positively for the sake of their environment and will have an impact on a moderate understanding of life (Yaqin, 2018; 957). This research does highlight the issue of religious moderation from a spiritual perspective, but it is not specific to the object of MATAN study. This research also only relies on library data, not directly confirmed in the field. 
Second, Meneguhkan Visi Moderasi dalam Bingkai Etika Islam; Relevansi dan Implikasi Edukatifnya, written by Fata Asyrafi Yahya (2018). This research reveals the relevance between Islamic ethics education and the vision of Islamic moderation. Moderation values can be obtained from the understanding of maqashid al-sharia that prioritizes the vision of benefit (Yahya, 2018; 476). Even though there are spiritual values in Islamic ethics, this research does not read specifically and deeply related to how the actual spiritual position in forming a moderate generation.

Third, Moderasi Berfikir untuk Menepati Tingkatan Spiritual Tertinggi dalam Beragama, written by Nirwani Jumala (2019). This research states that the development of spiritual character is the right step in realizing religious moderation. This is because spiritual character is the value of awareness of origin, purpose and destiny. Meanwhile, religion is a belief that is considered as the absolute truth of life (Jumala, 2019; 17). Unfortunately this research does not target religious and spiritual moderation in its relation to minimizing acts of radicalism and terrorism.

This research specifically portrays the teaching of religious moderation in an intellectual and spiritual framework in the case study of the Ahluth Thariqah Al-Mu'tabarah An-Nahdliyah (MATAN) Student in Bandung, West Java.

\section{Research Methods}

The research methodology used in this research is qualitative research, with a case study approach. The cases chosen were students who were followers of Ahlith Thoriqah Al Mu'tabarah An Nahdliyyah (MATAN) in Bandung, West Java Province. This research was carried out in 2020 with funding from the Center for Research and Development for Religious Affairs and Religious Services of the Ministry of Religion of the Republic of Indonesia. The data were collected through interview techniques, documentation, Focus Group Discussion (FGD) and literature study.

Interviews were conducted with key informants who were considered representative in providing an overview of the researchers' intentions. The interview was conducted with; first, Gus Iid (Secretary General of the Central MATAN) to obtain information on the movement of MATAN throughout Indonesia. Second, Nandang Suhendra (Chairman of MATAN Bandung) to get a complete picture of MATAN Bandung. Third, KH Muhammad Ridwan, chairman of the local Indonesian Ulema Council (MUI), to get a perspective on the Islamic condition of the Bandung people and his offer in dealing with radicalism. Fourth, Ajin (Secretary General) to obtain MATAN Bandung documents. Fifth, Mamay Yusfan Hadian (General Student of MATAN) to obtain information and motivation for public campus children to enter MATAN. Sixth, Iqbal Abu Hafsah (Tarbiyah Sunnah Radio Staff, Bandung) to provide views on Sufism and tarekat from a perspective that is contrary to MATAN, Seventh, Ghinan (MATAN Pebisnis Sympathizer) to get views from outside MATAN members. Eighth, Zian Ulfa Haq Nisa (Pemudi Jama'ah Mihrabul Muhibbin Jakarta), ninth, M Nurul Anwar (Pemuda Jama'ah Mihrabul Muhibbin Jakarta), and tenth, Eka AK (Tarekat Zawiyah Rumi Cafe Jakarta activist). From the last three informants, the aim is to get information about what motivations young people in the capital have in joining organizations that focus on the world of tarekat / Sufism that they participate in.

Meanwhile, a Focus Group Discussion (FGD) was conducted with several informants. First, Anton Tahqiq Fathoni (Secretary of JATMAN Bandung). Second, Cecep Suryana (FKUB Bandung). Third, Ruba Nurzaman (Pemuda Ansor Bandung). Fourth, Roma Salimuddin (Muhammadiyah Bandung Youth). Fifth, Irfan Firmansyah (Pemuda Persis Bandung). Sixth, Jajang Sugiarto (Member of MATAN ex-HTI). And Seventh, Jajang 
Nurhadi (Member of the ex-ISIS MATAN). FGD informants were presented to provide information and comments about the existence and movement of MATAN in Bandung in relation to the dissemination of religious moderation and minimizing radicalism and terrorism in Bandung. The documentation and library data are carried out by examining books and documents related to MATAN, Sufism, and its relation to religious moderation and minimizing radicalism and terrorism.

\section{Research Findings and Discussion Description of Intolerance and Presence of MATAN in Bandung}

Setara Institut also stated in his research on the potential features of fundamentalism among students. The research states that UIN Bandung and UIN Jakarta students get the highest score with the potential to be the root of exclusivism and intolerant behavior. UIN Bandung got 45.0 points and UIN Jakarta got 33.0 points (Setara Institut, 2016).

In West Bandung Regency (WBR) acts of intolerance also occurred in several places. One of them, from 2015 to 2020 , the construction of a parish church, a church under the diocese of Bandung, was still hampered due to rejection from local residents from four hamlets in Ciwaruga village, namely RW 16, 17, 18, and 19. As also emphasized by Cecep Suryana (FKUB WBR) refusal to build the church occurred in the Pondok Hijau Indah complex area, Ciwaruga Village, Parongpong District, WBR. According to Suryana, most of the rejection came from a group of young people (Interview with Cecep Suryana, 17 July 2020). Suryana's statement was confirmed by the Chairman of the Indonesian Ulema Council (MUI) WBR; Muhammad Ridwan, who stated that the internal problems of the millennial generation at WBR are due to several things, among which are stagnation in thinking, group fanaticism and divisions between religious communities (Interview with Muhammad Ridwan, 17 July 2020).

One form of intolerance in WBR is the insult committed by a young man from WBR who was sent to Habib Lutfi, Chairman of the Ahlith Thoriqah al Mu'tabarah Network within the Nahdlatul Ulama organization who later became the founder of Ahlith Thariqoh Al Mu'tabarah An Nahdliyyah (MATAN) students. ). Through caption memes distributed through social media, the young man created a hateful narrative against someone who was the Chairman of Jatman. The Facebook account, whose owner is from WBR, questioned Habib Lutfi's advice by saying that the practice deviated from the Al-Qur'an and the Sunnah. Habib Lutfi is considered not to be afraid of making new practices that are considered heretical and heretical and the place is hell (Interview with Friends of Ajin Sekjend MATAN WBR, 17 July 2020).

Getting to know the MATAN organization, the idea of establishing MATAN originated from a small discussion in the overhang in the residence of Habib Luthfi Bin Ali Bin Yahya on August 2, 2009, at. 15.30-17.00 WIB. The discussion took place between Dr. H. Hamdani Mu'in, M.Ag with KH. Dimyati Rois (Musytasyar PBNU 2010-2015 and Caregivers of Al-Fadhlu Islamic Boarding School, Kaliwungu). The activity was also attended by several students, namely: Abdul Rosyid, M.Mahfudz, Syariful Anam, Asep Syaiful Zulfikar, M.Ridlo, Kholid Abdillah, Nurul Mu'amar, Dedi Rosadi, Ubaidillah and Riyadli Muhlisin. The small discussion discussed concerns over the existence of the phenomenon of radicalism and pragmatism among students. KH. Dimyati is also appreciative and supportive of the spirituality and intellectual movements among the students that they are discussing. This history was also corroborated by Ra'is Syu'biyyah JATMAN Bandung, who emphasized that MATAN was founded to maintain spirituality by always being close to Allah, praying, staying 
away from drugs and so on which could become a bad image for young people (interview with Ma'mur Sa'adi, July 17, 2020).

The MATAN declaration was carried out in 2012, together with the XI JATMAN congress at the Bululawang Islamic Boarding School, Malang, East Java, to be precise on 1014 January $2012 \mathrm{M} / 16-20$ Shafar $1433 \mathrm{H}$. The congress agreed the birth of MATAN as the Mustaqillah Lajnah Body of JATMAN. . In closing the event, Ro'is' Am JATMAN; Habib Luthfi, declared MATAN.

The history of the establishment of MATAN Bandung Barat begins with the presence of a student named Kang Zaenal who attended the Cipasung Islamic Boarding School and became a student at the Cipasung Islamic Institute (IAIC), Tasikmalaya. Apart from being a student, he is also active in the student organization of the Indonesian Islamic Student Movement (PMII) at the local campus. When he finished his Islamic boarding school and college education he was entrusted by his teacher so that when he returned home he would remain active in Nahdlatul Ulama (NU). After returning to Tasikmalaya, he played in the Batujajar area, West Bandung, to meet Kang Ajin (a young man who would later become Secretary General of MATAN for the 2019-2021 period). During the meeting he talked about his mandate and at the same time asked about the regeneration of the NU Ansor Youth Movement (GP Ansor). Not long after, he joined the regeneration of Ansor. Two months after becoming a member of Ansor, he was called by Ajid Tahir, the chairman of MATAN in West Java, asking him to also establish MATAN in West Bandung as a realization of his teacher's mandate. He also with Ajin's best friend tried to gather young people in West Bandung to jointly establish MATAN in the West Bandung area. Finally, two months later, the first West Bandung MATAN board was immediately inaugurated at the same time as the inauguration of MATAN's Chairman of West Java at the State Islamic University (UIN) Bandung, directly inaugurated by Habib Luthfi Bin Ali Bin Yahya.

Following an organization or group of course because the organization has something important to its members. Gitosaroso said that the urgency of joining the tarekat is so that a person can understand the meaning of the worship he / she carries out seriously, so that the worship he performs actually has an impact on his behavior (Ridwan, 2018: 88). On the other hand, some of the benefits of the tarekat are as follows; first, cleansing the heart in interacting with Allah; second, cleansing oneself from material influence; third, fighting the soul from darkness; fourth, strengthening religious beliefs; and fifth, enhancing human morals (Amin, 2014: 84-86).

To be able to join a tarekat does not have to be old. The statement that the tarekat is only synonymous with parents is a statement commonly understood by the community. Apart from assuming that the tarekat is identical with the parents, it is also perceived as only for rural communities. (Mandar, 2019: 254). In fact, MATAN is a way for young people to easily get istiqomah. (Interview with Ma'mur Sa'adi, 17 July 2020). This basic assumption, according to Anton Tahqiq Fathoni, the chairman of JATMAN West Bandung, made many young people, even the NU generation itself, reluctant to follow the tarekat. They still think that it is not the time for them to bond (Interview with Anton Tahqiq Fathoni, 17 July 2020). MATAN's Concept of Religious Moderation

The dissemination of religious moderation in the MATAN organization can also be read through the affirmation of the concept. If you look at the elements of religious moderation in the book "Religious Moderation" of the Indonesian Ministry of Religion, the notion of religious moderation must at least fulfill four elements, namely national commitment, tolerance, anti-violence, and cultural accommodative. 
In terms of national commitment, MATAN has emphasized since its formation. Whereas, as a forum for the tarekat for young people, MATAN applies the intolerant, inclusive, and intolerant Ahlussunnah wal Jama'ah within the framework of the Republic of Indonesia by adhering to the ideology of Pancasila and the 1945 Constitution (SOP MATAN 2020, i-ii). In addition, according to Nandang Suhendra, the General Chairperson of MATAN, he said that in addition to a combination of spirituality and intellectuality, MATAN adheres closely to the spirit of nationalism (Interview with Nandang, 17 July 2020). The chairman of MATAN Bandung framed himself that MATAN was indeed an organization of young people who, apart from being steadfast in God's rules, was also loyal to the concept of Indonesian statehood. This is important to make MATAN open to young nationalists to join the organization. In addition, members of the former ISIS and HTI MATAN emphasized that after they entered MATAN they realized wholeheartedly that the UUD, Pancasila and NKRI were basically full of Islamic values, which prioritize equality, tolerance and togetherness. Both Pancasila and UUD 45 are not products of kafir, but the result of ijtihad between the nation's founding fathers to find a common ground for diversity in Indonesia (Interview with Jajang and Jajang Sugiarto, 17 July 2020). In fact, the very first goal of MATAN being established was to defend Pancasila and the 1945 Constitution as the state ideology (SOP MATAN, 2020: 4). With efforts to frame itself as an organization that adheres to the concept of an Indonesian state, MATAN is important to get support and mass from young people so that they can join the organization.

MATAN's tolerant attitude can also be read through MATAN's SOP in CHAPTER V Article 6 concerning character, at the point that the characteristics of MATAN are as a servant, which focuses on solemnly to the people in a full heart, accurate and fast manner. For example, this attitude of tolerance was born in the absence of coercion for the youth of Nahdlatul Ulama (the parent organization of JATMAN and MATAN) to enter the MATAN organization (Interview with Nandang, 17 July 2020). Another butki is the opening of MATAN to accept all groups, even non-Muslims. Therefore, in the context of this tolerance MATAN also accepts members of the former ISIS (Jajang), HTI (Jajang Sugiarto), even as according to the Secretary General MATAN, accepting several members of the Islamic Defenders Front (FPI). The author understands this as MATAN's attempt to get out of the circle of influence of the understanding of NU cadres who generally understand FPI and HTI as a radical organization. MATAN actually embraces these groups in an effort to enlarge its organization.

The commitment to non-violence is one of the elements of MATAN's dissemination to its members. As the character of Sufis who avoids oppositional attitudes, let alone violence, MATAN is against carrying out extreme activities, even from the moment they are in mind. Mamay emphasized that MATAN avoids committing violence because of consideration of calmness or lack of heart in doing everything (Interview with Mamay, 17 July 2020). This effort was made to frame itself as a religiously devout organization by making the MATAN organization an anti-violence organization. This commitment, for example, was manifested in the form of not taking physical action when facing someone who bullied Habib Lutfi and the inactivity of MATAN members in dealing with hoax news and splits during the 2019 Presidential Election (Mamay Interview, 16 July 2020).

The final commitment in affirming MATAN Bandung's religious moderation is cultural accommodative. It can be seen from at least three things. First, there are many MATAN members who are active in the Kaji Musician Community (KOMUJI) Bandung. Second, the opening of MATAN to accept members with background singers and musicians. 
And third, interpreting music as a way of comforting the hearts of young people to remember Allah (Interview with Nandang, 17 July 2020). This necessity can also be read as an attempt by MATAN to frame itself as a collaborative organization towards cultural values. It is important that MATAN is not only accepted by young people with Islamic backgrounds, but also by people with an interest in culture.

\section{Implications of MATAN's Religious Moderation}

This sub-chapter is a reflection on the findings of the concept, character and dissemination of the ideology of religious moderation in MATAN. In the theory of religious group mobilization, this can be said to be the success of MATAN leaders in organizing their members so that they succeed in bringing MATAN as a religious organization that is considered good for the surrounding youth, especially in West Bandung. The dissemination that is implemented in this youth ketasawufan organization has an impact on its members and also on the surrounding environment. There are several things that have a positive effect on the dissemination of the moderation ideology, namely as follows:

HTI Sympathizers Awareness. Is Jajang Sugiarto, a former activist of Hizbut Tahrir Indonesia (HTI). As is well known, HTI is one of the former Islamic organizations in Indonesia which aspires to establish an Islamic caliphate Islamic state. HTI rejects all elements which for them are not compatible with Islamic law, such as the ideology of Pancasila, the 1945 Constitution, and the Unitary State of the Republic of Indonesia (NKRI) (Rasyid, 2017: 18). Jajang, Jajang Sugiarto's nickname, became a sympathizer of HTI starting from his dependence on reading HTI's social media, such as the Hizbut Tahrir Indonesia website and Ummat Media. Apart from that, he also depends on reading HTI bulletin which is distributed in mosques, such as Al-Islam and Al-Wa'ie. Jajang only read and believed it completely and did not confirm it with anyone for 8 months. Some time later Jajang realized that what he believed during his time as HTI was not true. himself did not find peace of mind while fighting for the ideals of HTI's citta. The religious practices that exist within the organization are only ambitious and even rebellious. when he entered MATAN in 2018, he was able to find peace of mind and heart.

Awareness of ISIS sympathizers. Jajang Nurdianto was originally an ISIS sympathizer. Jajang became an ISIS sympathizer because of the psychological factors behind him since he was in junior high and high school. In the past, he studied in an exclusive Islamic boarding school. After graduating from high school, he worked in Batam. While he was overseas, he learned a lot and read through social media, especially Facebook and Youtube. During the period of 1 year he was much interested in the narratives and videos presented by the ISIS group in the form of physical jihad and warfare. Meanwhile, Jajang seemed to have found the right Islamic momentum. He felt that the Islam displayed by the ISIS group was a brave, existing, and not half-hearted Islam like most Muslims, who just sit quietly in preaching, without taking up arms. After he returned to West Bandung, he began studying at the Darul Falah Islamic Religious College (STAI). During the lecture he read a lot of books, discussed with MATAN members, one of which was Mamay Yusfan Hadian. During the discussion with MATAN members there were many changes he had.

\section{Conclusion}

This research concludes that MATAN is an organization of tarekat young people that is identical to an organization that harmonizes intellectual and spiritual values. These two dimensions are important for fostering an attitude of moderation towards its members and also the surrounding community. MATAN's conception of religious moderation by harmonizing 
intellectual and spiritual roles is contained in the lines of social, Sufism, politics, culture and religion. The character of religious moderation in MATAN is in line with the moderation character mentioned by the Ministry of Religion, namely the existence of tolerance with other groups, such as FPI, HTI and even ISIS; commitment to nationality, in which MATAN has a vision and mission to reinforce the concept of the State of the Republic of Indonesia and its ideology, namely Pancasila; anti-violence, by facing radicalism with an intellectual and spiritual approach; and cultural accommodation, by networking with the Kaji Musician community and by investing in the members' economy by doing several businesses, such as Koi fish farming and selling T-shirts.

The dissemination of religious moderation in MATAN has resulted in the awakening of some ISIS and HTI sympathizers to join the organization. This is a positive result that arises from organizing the Chair of MATAN for its members in framing the harmonization of intellectual and spiritual roles in organizational life.

This research recommends to the government; that is, so that the movement of young people who are members of organizations such as MATAN will provide access to development in campuses, high schools and junior high schools. So far, this has been an obstacle for MATAN so that it is less widespread in educational institutions. In fact, secondary and tertiary educational institutions are very prone to become a field for the growth of radicalism and terrorism. If possible, MATAN youths can become partners in the prevention of terrorism radicalism among young people at the junior, high school, and university levels.

\section{References}

[1] Akmansyah, M. (2016). "Membangun Toleransi Dalam Perspektif Pendidikan Spiritual Sufistik", dalam jurnal Kalam, Vol. 10, No. 2, Desember.

[2] Al-Ghazali, (t.th). Ihya Ulum Ad-Din, Kairo: Dar Al-Kutub Al-Islamiyyah.

[3] Ali, Lukman Ali, dkk, (1994)dkk. Kamus Besar Bahasa Indonesia, Jakarta: Balai Pustaka.

[4] Amin, Amin (2015). Zuhr al-Islam, Beirut: Dar al-Kitab al-'Arabi.

[5] Amin, Samsul Munir (2014). Ilmu Tasawuf, Jakarta: Amzah.

[6] Anam, Choirul (2014). Ensiklopedia Nahdlatu Ulama, Jakarta: PBNU.

[7] Annangguru, Acco Musaddad (2019). Perubahan Sosial di Mandar, Mandar: Gebyar Visual.

[8] Ardiyansyah (2019). Memebela Islam dengan Cinta, Jakarta: Quanta.

[9] Arraiyyah, M. Hamdar (1993). "Kehidupan Penganut Tarekat Naqsabandiyah Khalidiyah di Pati, Jawa Tengah", dalam jurnal Tasawuf, Vol. 9, No. IV.

[10] Aslamiah, Suwaibatul (2017). "Pendidikan Spiritual Sebagai Benteng Terhadap Kenakalan Remaja: Sebuah Kajian Terhadap Kisah Nabi Yusuf”, dalam jurnal LEGALITE, Vol. II, No. 01.

[11] At-Thabari, Imam, 1412 H). Jami Al-Bayan fi Tafsir Al-Quran, Beirut: Dar al-Ma'rifah.

[12] Bainbridge, William Sim dan Rodney Stark, (1996). A Theory of Religion, New Jersey: Rutgers University Press.

[13] Beckford A, James (1986). New Religious Movement and Rapid Social Chane, London: SAGE Publication Inc.

[14] Burhani, Ahmad Najib (2019). Menemani Minoritas, Jakarta: Gramedia Pustaka.

[15] Choirunnisa, Ninis. Survei Alvara Institut: 20 Persen Pelajar dan Mahasiswa Rela Berjihad, dikutip dari nasional.tempo.co.

[16] Darmadi, Dadi. Guru Agama Makin Tak Toleran, dalam https://ppim.unjkt.ac.id.

[17] Dimyati (2016). Dakwah Personal: Model Dakwah Kaum Naqsabandiyah, Jakarta: Deepublish.

[18] Emawati, dkk (2015). Tarekat Qadiriyah Naqsabandiyah: Studi Etnografi Tarekat Sufi di Indonesia, Yogyakarta: Deepublish.

[19] Faiza, Arum dan Sabila J Firda (2018). Arus Metamorfosis Milenial, Kendal: CV. Ahmad Jaya 
Group.

[20] Frager, Robert (2005). Psikologi Sufi, Jakarta: Serambi.

[21] Gazali (2015). Tarekat Naqsabandi Haqqani di Indonesia, Yogyakarta: Deepublish.

[22] Ghazali, Muhammad Ibn Muhammad (1907). Khulasah At-Tashannif al-Tasawuf, Maghrib: Mathba'ah al-Najah.

[23] Hamdani, Jamil (2020). "Al-tasamuh al-Shufi wa al-thuruq al-Maghrib”, dalam http://almothaqqof.com, diakses pada 11 Agustus.

[24] Hidriyah, Sita dan Victor Muhammad (2019). Kerjasama Internasional Melawan Terorisme, Jakarta: Pustaka Obor Indonesia.

[25] Hudaeri, Moh. (2010). "Debus di banten: Pertautan Tarekat dengan Budaya Lokal", dalam jurnal AlQalam, Vol. 27, No. 1, Januari-April.

[26] Jaiz, Hartono Ahmad (1999). Mendudukkan Tasawuf: Gus Dur Wali?, Universitas Michigan.

[27] Jumala, Nirwani (2019). "Moderasi Berfikir untuk Menepati Tingkatan Spiritual Tertinggi dalam Beragama”, dalam jurnal SUBSTANTIA, Vol. 21, No. 2, Oktober.

[28] Kabbani, Syaikh Muhammad Hisyam (1998). Tasawuf dan Ihsan, Jakarta: Serambi.

[29] Kementerian Agama RI (2018). Survei Kerukunan Umat Baragama, Jakarta: Litbang Kemenag RI.

[30] Kementerian Agama RI (2019). Survei Kerukunan Umat Baragama, Jakarta: Litbang Kemenag RI.

[31] Khanafie, Imam, (2013). Tarekat Kebangsaan: Kajian Antropologi Sufi Terhadap Pemikiran Nasionalisme Habib Luthfi, jurnal Penelitian, Vol. 10, No. 2, November.

[32] Lubis, Nina Herlina (2000). Sejarah Kota-Kota Lama di Jawa Barat, Jakarta: Alqaprint Jatinangor.

[33] MATAN (2020). SOP, Juknis dan Pedoman Penyelenggaraan Tertib Administrasi Mahasiswa Ahlith Thoriqoh Al Mu'tabarah An Nahdliyyah Tahun 2020.

[34] Mustaqim, Abdul (2019). At-Tafsir Maqashidi, Yogyakarta: Penerbit IDEA.

[35] Nafi', M. Zidni. Dilantik, MATAN Jabar Kembangkan Pendidikan Spiritual di Kampus, diakses melalui www.nuonline.com.

[36] Narvaez Darcia dan Larry Nucci (2014). Handboox of Moral and Character Education, London: Routladge.

[37] Nashar, Muhammad, dkk (2010). Kontribusi Posdaya Masjid Miftahul Huda, Jakarta: Duta Media Publishing.

[39] Nasir, Amin (2016). "Hubungan Tasawuf dengan Spiritualitas (Meneropong Kedalaman Sejarah Sebagai Fenomena Mistisisme Spiritual”, dalam Esoterik; Jurnal Akhlak dan Tasawuf, Vol. 2, No. 2.

[40] Noorhaidi, Hasan. (2006). "Islam Politik, Teori Gerakan Sosial, dan Penacrain Model Pengkajian Islam Baru Lintas-Disiplin”, dalam, Al-Jamiah Vol. 44, No. 02.

[41] Pudjiastuti, Tri Nuke. LIPI: Gerakan Radikal Masuk Ke Kampus, diakses melalui lipi.go.id.

[42] Putra, Andi Eka (2016). "Islam Toleran; Membangun Toleransi dengan Jalan Spiritual", dalam jurnal Kalam, Vol. 10, No. 2, Desember.

[43] Rasyid, Muhammad Makmun (2017). HTI Gagal Paham Khilafah, Ciputat: Pustaka Compass.

[44] Ridwan, Gitosaroso (2018). Shalat dalam Perspektif Tarekat, Jakarta: Pustakapedia.

[45] Rina, Pismawenzi dan Novia (2015). "Tarekat Naqsabandiyah dan Pembinaan Mental Remaja", Jurnal Al-Qalb, Vol. 7, No. 1, Maret.

[46] Saifuddin, Lukman Hakim (2019). Moderasi Beragama, Jakarta: Balitbang Diklat Kemenag RI.

[47] Setiawan, Kendi. Tiga Kunci Wasathiyyah Menurut Quraish Shihab, diakses melalui www.nuonline.com.

[48] Shihab, M. Quraish (2020). Washatiyah; Memahami Islam Tentang oderasi Beragama. Ciputat: Lentera.

[49] Sholikin, Muhammad (2010). Menyatu Diri Dengan Ilahi, Jakarta: NARASI.

[50] Sulaeman, Dina Y (2017). Libya, Suriah, dan Keruntuhan Anti Kekerasan HTI, dalam www.geotimes.

[51] Sulaiman (2015). "Membaca Pancasila: Perspektif Kearifan Sufi Jalaluddin Rumi”, dalam Jurnal Kebudayaan Islam, Vol. 13, No. 1, Janauri-Jnui.

[52] Turmudzi, Endang (1998). "The Tarekat Qadiriyah Wa Naqsabandiyah in East Java and Islamic Politic in Indonesia”, dalam Southeast Asian Journal of Social Science, vol. 26, No. 2.

[53] Veithzal (2014). The Economics of Education, Jakarta: Gramedia Pustaka. 
[54] Wickham, Carrie Rosefsky (2002). Mobilizing Islam: Religion, Activism, and Political Change in Egype, New York: Columbia University Press.

[55] Wictorowick, Quintan (2002). Gerakan Sosial Islam: Teori, Pendekatan dan Studi Kasus, terj. Tim Penerjemah Yayasan Wakaf Paramadina, Yogyakarta: Gading Publishing dan Yayasan Wakaf Paramadina.

[56] Yahya, Fata Asyrafi (2018). "Meneguhkan Visi Moderasi dalam Bingkai Etika Islam; Relevansi dan Implikasi Edukatifnya", Proceding Annual Conference for Muslim Scholar, April.

[57] Yaqin, Muhammad Ainul (2018). "Dzikir Manaqib; Moderasi Islam di Tengah Masyarakat Multikultural”, Proceding Annual Conference for Muslim Scholar, April.

[58] Zainal, Achmad Zainal (2019). website UIN Suka, Juli.

[59] Zamroni, Imam Zamroni (2006). "Islam, Pesantren dan Terorisme", dalam Jurnal Pendidikan Islam, Vol. II, No. 2. 